\title{
Equal pay by gender and by nationality: a comparative analysis of Switzerland's unequal equal pay policy regimes across time
}

\author{
Roland Erne and Natalie Imboden*
}

\begin{abstract}
What explains the adoption of two different policies on equal pay by gender (EPG) and by nationality (EPN) in Switzerland? And why is the liberal, litigation-based, equal pay policy regime set up by the Gender Equality Act of 1996 much less effective than the neocorporatist 'accompanying measures' to the Bilateral European Union-Switzerland Agreement on Free Movement of Persons adopted in 1999 to ensure equal pay for workers of different national origins? The formation of two different policy regimes cannot be explained by different levels of political will. Equally, different 'varieties of capitalism' cannot explain the setup of the two different equal pay policy regimes within the very same country. Instead, our qualitative comparative analysis across time suggests that the differences can be best explained by a particular constellation of attributes, namely the use of different policy frames-i.e. 'anti-discrimination' in the EPG and 'unfair competition' in the EPN case- and the different setting of interest politics epitomised by the opposite stances adopted by Switzerland's employer associations in the two cases.
\end{abstract}

Key words: Equality, Gender, Migrant workers, Equal pay, Switzerland, European Union

FEL classifications: J61, J71, J88

\section{Introduction}

This article seeks to explain the establishment of two different equal pay policy regimes in Switzerland-i.e. equal pay by gender (EPG) and equal pay by nationality (EPN) - as well as their unequal effectiveness. The period under scrutiny stretches from the late 1990s, when Swiss policymakers enshrined both the EPG and EPN principles in law, to 2014, when it became evident that both equal pay policy regimes

Manuscript received 27 September 2013; final version received 6 January 2015.

Address for correspondence: Roland Erne, School of Business, University College Dublin, Belfield 4, Dublin, Ireland; email: Roland.Erne@ucd.ie

* University College Dublin (RE) and Unia, Berne, Switzerland (NI). Roland Erne would like thank the Transnational Labour Group at the Centre for Advanced Study in Oslo and Natalie Imboden the School of Business at University College Dublin, for the two visiting fellowships that gave them the time and space to complete this research.

(C) The Author 2015. Published by Oxford University Press on behalf of the Cambridge Political Economy Society. All rights reserved. 
were facing new challenges, albeit for different reasons. Whereas employer associations rejected a further strengthening of the EPN policy regime in 2013, as was often the case when neocorporatist arrangements became too restrictive for capital in the past (Schmitter and Grote, 1997), the government proposed in October 2014 a reinforcement of the EPG law (Bundesrat 2014), despite employer resistance. In so doing, the government was following the advice of a governmental expert group that criticised the existing EPG regime as ineffective and suggested new EPG enforcement measures, including mandatory audits of companies' payroll accounts (Müller et al., 2013). Incidentally, it is precisely this measure that proved to be a central feature in Switzerland's EPN regime.

In 1996 the Gender Equality Act (GEA) came into force to provide mechanisms to redress violations of the principle of equal pay for work of equal value for men and women. As far back as 1981, the Swiss people had approved a corresponding constitutional amendment by referendum and, on the 10th anniversary of the amendment in 1991, the Swiss Federation of Trade Unions (SGB-USS) organised a widely followed national women's strike for its implementation. In 1999 the Swiss people also approved several bilateral agreements with the European Union (EU) by referendum, including the bilateral Agreement on the Free Movement of Persons (AFM) between the EU and Switzerland in conjunction with a package of 'accompanying measures' that ended an era of unequal legal treatment of workers of different origins on the Swiss labour market. Whereas the accompanying measures aim at the prevention of 'unfair competition' or 'social dumping' in the Swiss labour market, the AFM introduced into Swiss law the principle of 'equal treatment' for European workers regardless of their nationality. ${ }^{1}$

If one compares the GEA's enforcement mechanisms on equal pay with those of the accompanying measures, one is struck by the different implementation strategies employed in the two cases. The enforcement of equal pay for men and women relies on litigation, which means that remedies must be sought by individual plaintiffs through the court system; nota bene in a situation in which there is no meaningful protection against unjustified dismissals. ${ }^{2}$

Thus, Switzerland's EPG regime mirrors the individualistic labour market regime that is characteristic of countries that are usually classified as 'liberal market economies' (LMEs). In contrast, Switzerland's EPN regime mirrors the neocorporatist patterns that exemplify 'coordinated market economies' (CMEs). Accordingly, infringements

\footnotetext{
1 'An employed person who is a national of a Contracting Party may not, by reason of his nationality, be treated differently in the territory of the other Contracting Party from national employed persons as regards conditions of employment and working conditions, especially as regards pay, dismissal, or reinstatement or re-employment if he becomes unemployed' (Annex 1, Article 9, AFM-Agreement between the European Community and its Member States, of the one part, and the Swiss Confederation, of the other, on the free movement of persons). Whereas it has been established that the AFM prohibits direct and indirect discriminations of EU workers in Switzerland (Kantonsgericht Basel-Landschaft, 2012; Schweizerisches Bundesgericht, 2013), the Swiss courts have not yet decided whether the AFM obligates employers to pay workers equal pay for work of equal value or just equal pay for equal work.

2 Unions or women's organisations 'may in their own names have a finding of discrimination declared if the probable outcome of proceedings will have an effect on a considerable number of jobs' (Article 7, GEA). But even if a court confirms discrimination in response to a collective complaint, each affected individual must file a personal redress claim in the courts for compensation in turn. This, however, is a risky endeavour, as unjustified terminations of employment contracts remain valid under Swiss labour law. Unfairly dismissed employees are entitled only to an indemnity that is determined by a judge but cannot exceed six months' wages.
} 
of the principle of EPN are usually not the subject of court proceedings, despite the AFM's explicit direct and indirect anti-discrimination provisions. ${ }^{3}$ Instead, this principle is enforced by bi- or tripartite commissions that have obtained extensive investigation and enforcement powers following several legal changes resulting from the 'accompanying measures' to the AFM. Thus victims of pay discrimination frequently alert a union about their circumstances. Subsequently, the union usually requests an audit of the suspected company's payroll accounts by the competent commission, without revealing the name of its informant. Likewise, individual companies can suggest an examination of a competitor's payroll account to ensure a level playing field in a given economic sector.

If one compares the number of enforcement actions taken by tripartite commissions to impose equal pay for workers of different national origins with the number of gender-related pay discrimination cases that are taken to Swiss courts, one is also struck by the huge difference in the policing and enforcement of equal pay policies in the two areas. Whereas tripartite commissions checked the payroll accounts in over 35,000 companies in 2010, the Swiss courts examined fewer than 100 gender-related pay discrimination cases in the same year. Given that origin-based pay discrimination is significant in specific sectors with a high percentage of posted workers while genderrelated pay discrimination is prevalent everywhere, the unequal enforcement of equal pay policies across gender and national origin is even more puzzling. ${ }^{4}$

The focus of this qualitative comparative analysis (QCA) across time is the development of two equal pay regimes that occurred at the same time within the very same country. This allows us to avoid the inherent methodological nationalism of the 'varieties of capitalism' (VoC) literature (Crouch, 2009; Erne, 2013). Nonetheless, the VoC literature provides us with useful insights (Rubery, 2011), even if pay gaps are rising in some CMEs, notably due to the growth of a non-unionised low-wage sector in countries without statutory minimum wages. In Germany for example, the low-paid part-time 'mini jobs' created by the supply side-oriented 'Hartz reforms' amounted 'to nearly 7 million workers in May 2005, of whom 70 per cent are women' (Fagan et al., 2006, p. 582; see also Smith, 2012). What makes the VoC literature intelligent is not the use of stylised 'national models' by some of its followers, but its holistic approach, according to which interrelated complementary configurations - rather than individual independent variables - explain socio-economic outcomes. Accordingly, we have chosen a qualitative comparative research design, which distinguishes itself from conventional quantitative approaches by its configurational approach and its search for set relations (Fiss, 2007; Schneider and Wagemann, 2012).

${ }^{3}$ The private sector union, Unia, recently backed an EPN-related test litigation case. In the case, the courts ruled that the selective enforcement of wage cuts by an engineering company through a notice of 'dismissal pending a change of contract' that was sent only to Grenzgänger (employees who live abroad and commute daily across borders to go to work) and not to its local workforce violated the AFM's anti-discrimination clause. The Grenzgänger who challenged the discriminatory wage cuts nevertheless lost their jobs (and therefore any future claims for wage payments). The courts in turn only obliged the employer to cover the litigation costs for its former employees, to pay outstanding overtime pay and compensation equal to four monthly salaries for 'abusive dismissal' (Kantonsgericht Basel-Landschaft, 2012; Schweizerisches Bundesgericht, 2013).

4 The fewer than 100 EPG cases taken in 2010 should be compared with Switzerland's pay gap of $13.3 \%$ in the public and $21.1 \%$ in the private sector (Eurostat, 2013) and its comparably large female labour force. In 2012 the female employment rate in Switzerland was $61 \%$. This figure is above the Swedish female employment rate $(60 \%)$, the EU member state with the highest figure, and well above the rate in its neighbouring countries: Austria, 55\%; Germany, 54\%; France, 52\%; and Italy, 40\% (United Nations Economic Commission for Europe, 2013). 
The next section justifies our study's approach in relation to the existing literature and presents a set of common and distinctive factors that provide the basis for our QCA across time. We then assess the formation and unequal effectiveness of the two Swiss equal pay policy regimes - for men and women (Section 3) and for workers of different origins (Section 4) - in greater detail across time. We focus our analysis on the dynamics within and between employers, unions and women's organisations, given the important role played by interest politics in the socio-economic sphere. Finally, the chronological accounts of the process of the policymaking trajectories in the two parallel cases are used to assess the explanatory power of the different factors included in the 'truth table' of our QCA.

\section{Assessing equal pay and varieties of capitalism: a 'natural' experiment}

Although equal pay for men and women for work of equal value is the legal norm in almost all LMEs, comparative political economists have shown that wage inequalities of all kinds tend to be smaller in CMEs. Accordingly, using aggregate national measures, such as union density or collective bargaining coverage (Blau and Kahn, 2003; Rueda and Pontusson, 2000), scholars have explained a large part of the international differences in the gender pay gap in terms of different national labour market institutions. Given the unavoidably aggregate nature of the measures on which cross-national quantitative studies rely, it is difficult to ascertain which specific labour market and equal pay policy mechanisms explain pay gaps across countries. This is either because reliable comparative measures are not available ${ }^{5}$ or because national differences in pay and pay inequalities can be caused by a wide array of explanatory factors that are not amenable to effective control. ${ }^{6}$

One way of advancing our knowledge on the relationship between pay gaps, equality law and labour market institutions consists in also adopting complementary analytical approaches (Galtung, 1990), as has been done by many qualitatively oriented scholars who have analysed different equal policy regimes at the national or workplace level. Given that the quantitative comparative literature in the field confirms that CMEs are better at reducing income inequalities, it is striking that a clear majority of qualitative studies are situated in LMEs.

English-speaking scholars are divided between (i) those who criticise the overly prescriptive, complex and therefore presumably ineffective hard law and (ii) those who fustigate the weak contribution of soft law, corporate social responsibility policies and voluntarist industrial relations in addressing the gender pay gap (McLaughlin, 2014; Deakin et al., 2013; Conley, 2012; Dickens, 1999). This polarisation of the debate, however, may be neither a consequence of a universal truth, i.e. the unavoidably autopoietic nature of the legal subsystem of society (Luhmann, 1989), nor the result of the ignorance of those who fail to see the way out of Luhmann's system theory offered by 'reflexive regulation' (McLaughlin, 2014, p. 4). Instead, this polarisation

\footnotetext{
${ }^{5}$ Even the most frequently used labour market indicators are not unproblematic, as the supposedly internationally comparative data published by international organisations such as the 'union density rate' or 'collective bargaining coverage rate' often mean different things in different countries (Erne, 2014, pp. 238-9).

${ }^{6}$ National wage developments and inequalities are also affected by a country's location in the global economy and its particular developmental trajectory, transnational labour migration and other social norms and structures that affect the production and reproduction of a country's labour force, including the division of paid and unpaid work (Sassen, 1988; Stan and Erne, 2014).
} 
may simply be a contingent consequence of LMEs' notorious difficulties with binding institutions of social coordination that are supported by hard law but are not enforced through the court system, as is so common in CMEs. After all, CMEs' neocorporatist institutions do not depend on the reflexive nature of deliberation processes, but rather on the constraining nature of their bargaining institution as well as on a balance of class forces between capital and labour, which make deliberations possible in the first place (Grote and Schmitter, 1999). Although many neocorporatist arrangements that characterise CMEs have proved beneficial for employers as a group, they have nevertheless limited the management prerogative of individual employers (Streeck, 1997). We have therefore chosen to study equal pay policies in a country in which political 'entrepreneurs' make use of both liberal and coordinated approaches to social regulation. Even if corporatist arrangements play a central role in the Swiss case (Kriesi and Trechsel, 2008), the concomitant presence of 'redundant' liberal features may not only be crucial in explaining institutional change across time, as shown by Colin Crouch (2005), but also internal variation across sectors and policy areas.

Our selection of two parallel cases also provides us with a genuine QCA research design (Ragin, 1989; Caramani, 2009; Schneider and Wagemann, 2012). Although the explanatory factors that we are assessing are not controlled in the traditional sense of a randomised experiment, our study can be viewed as a natural experiment because our deliberate case selection allows us to control for a wide range of explanatory factors. Our parallel cases triggered both liberal and neocorporatist equal pay policy regimes, even though they evolved within the same political system during the same time period - involving the same government, population, political parties, unions and employer organisations. Our comparative analysis is thus based on a 'most similar case' design that allows us to control for factors recurrently used to explain the use of different regulatory designs across countries. This allows us to systematically assess alternative explanatory factors to explain different policy outcomes, namely levels of political will, dynamics between interest groups, social movements, political parties and the government and a different framing of the policy problem in public policy debates. As the principle of equal pay for work of equal value in both Swiss cases was approved in parliament and in popular referenda with similar majorities, the different outcomes cannot be explained by diverging levels of political will and support. However the role played by interest groups and social movements differed substantially. Whereas Swiss employer organisations supported the accompanying measures that entailed the equal pay principle for workers of different origins, they opposed the GEA. As a result, policymakers could not rely on corporatist mechanisms to implement equal pay policy for men and women and this undoubtedly undermined its effectiveness. But why would employers reluctantly accept equal pay policies in one field and not in another? After all, both policies entail additional costs for capitalists. Following economic sociologists and public policy analysis showing that both markets and social policies are social constructs (Muller, 2005; Naumann, 2005), this article explains the unequal success of the equal pay policies also in terms of the different frames of reference employed in the two cases. Table 1 reiterates the set of explanatory factors mentioned above and indicates their values based on the following in-depth assessment of each case.

Too often the values included in QCA 'truth tables' are the result of approximations rather than of a long-term engagement with the research field. Consequently, the reliability of the empirical information captured in Table 1 must be corroborated by a detailed assessment of the processes of policy formation and implementation across 
time. Therefore the next two sections trace the activities of all actors involved in these processes, namely federal and cantonal administrations, parties, unions, employer organisations and women's organisations. Our research is based primarily on an analysis of documents published by federal and cantonal authorities, political parties, unions, employers' organisations and women's and migrants' associations between 1990 and 2014. In addition we had numerous conversations with equal opportunities officers, industrial relations practitioners and public representatives. We were also able to observe internal discussions on equal pay within Swiss trade unions, feminist groups and bi- and tripartite commissions on various occasions between 1990 and 2014 .

\section{Equal pay for men and women: a liberal solution with limited effects}

Swiss gender equality policy developed outside the corporatist networks that characterise the country's employment policy regime. Several collective labour agreements (CLA) include gender equality provisions, but there is little coordination between the confederation's gender equality policy and those developed through industrial relations. Given its direct democratic institutions, however, the country is very open to influences from civil society.

Table 1. Switzerland's unequal equal pay policies by gender and by nationality

\begin{tabular}{|c|c|c|}
\hline & $\begin{array}{l}\text { Gender } \\
\text { Equality Act }\end{array}$ & $\begin{array}{l}\text { Bilateral Agreement on the } \\
\text { Free Movement of Persons } \\
\text { and accompanying measures }\end{array}$ \\
\hline \multicolumn{3}{|c|}{ Factors that explain the enactment of the equal pay principle in both cases } \\
\hline Political support (population) & Yes & Yes \\
\hline Political support (parliament) & Yes & Yes \\
\hline $\begin{array}{l}\text { Interest group support } \\
\text { (trade unions) }\end{array}$ & Yes & Yes \\
\hline \multicolumn{3}{|c|}{ Factors that explain the enactment and unequal design of the two equal pay policy regimes } \\
\hline $\begin{array}{l}\text { Dominant policy framework } \\
\text { (anti-discrimination) }\end{array}$ & Yes & $\mathrm{No}^{\mathrm{c}}$ \\
\hline $\begin{array}{l}\text { Interest group support } \\
\text { (women's organisations) }\end{array}$ & Yes & NA \\
\hline $\begin{array}{l}\text { Liberal regulatory strategy } \\
\text { based on individual litigation }\end{array}$ & Yes & No \\
\hline $\begin{array}{l}\text { Dominant policy framework } \\
\text { (fair competition) }\end{array}$ & No & Yes \\
\hline $\begin{array}{l}\text { Interest group support } \\
\quad \text { (employer associations) }\end{array}$ & No & Yes \\
\hline $\begin{array}{l}\text { Neocorporatist regulatory } \\
\text { strategy (payroll audits by } \\
\text { tripartite commissions with } \\
\text { law enforcement powers) }\end{array}$ & No & Yes \\
\hline \multicolumn{3}{|l|}{ Policy outcomes } \\
\hline $\begin{array}{l}\text { Effective enforcement } \\
\text { of equal pay policy }\end{array}$ & No & Yes \\
\hline
\end{tabular}

\footnotetext{
aThe Gender Equality Act enshrines equal pay for work of equal value for men and women.

'The bilateral Agreement on the Free Movement of Persons and the accompanying measures enshrine equal pay for all EU/EEA workers in any one location, irrespective of their country of origin.

${ }^{\mathrm{c}}$ The AFM nevertheless also outlaws any direct and indirect discrimination based on nationality.
} 
Since 1981 the legal equality of women and men and the principle of equal pay for work of equal value have been enshrined in the Swiss Constitution. This followed a popular initiative entitled 'Equal Rights for Men and Women', which resulted from the political mobilisation of the women's movement in both its traditional and modern forms (Chaponnière-Grandjean, 1983; Joris and Witzig, 2001). The 1981 constitutional amendment led to new legislation governing marriage and the GEA, which came into force in 1996. It gave effect to the right to equal pay for work of equal value enshrined in the Constitution and prohibits discrimination in employment in principle. The adoption of the act was preceded by a huge mobilisation of women's organisations and unions, including a successful national 'women's strike' on 14 June 1991, involving around half a million women, i.e. more women than were actually union members. The strike was called by the unions on the 10th anniversary of the vote on the 1981 equal rights amendment to protest against the failure to implement the Constitution's equality principle.

The GEA has been celebrated as a milestone in gender equality policy in employment. Apart from granting women's access to litigation, however, the GEA does not contain any effective enforcement mechanisms; this means that GEA implementation has effectively been individualised. Proactive state action in monitoring gender pay gaps relates only to the public procurement process. Although the principle of equal pay has been enshrined in law, its implementation is largely left to the affected employees; this means that Swiss gender equality policy relies on a 'liberal' public policy regime (Fuchs, 2008, 2010; Imboden, 2008). Up to 2013, around 600 gender discrimination cases had been documented, with 2009 being a record year when 128 cases were brought in the German-speaking parts of Switzerland alone. One half of all cases relate to pay and the majority of cases are from the public sector: in administration, education, health and social care. A number of successful union-sponsored litigation cases in the public service, brought by healthcare workers and kindergarten teachers, led to substantial wage increases and back payments (Fuchs, 2013).

In comparison to the UK, where strategic litigation became the primary strategy in the fight against the pay gap (Guillaume, 2013; Deakin et al., 2013; Dickens, 2006), equal pay claims occur less frequently in Switzerland. In comparison to the derisory low figures of equal pay litigation in Germany (31 cases), France (16 cases) and Poland (one case) during the period (1996-2007), the 49 Swiss equal pay cases during same time frame do stand out (Fuchs, 2013). Given the lack of protection against revenge dismissals, Fuchs' classification of Switzerland's gender equality regime as a case of a 'strong legal opportunity structure' seems to be rather far-fetched. Certainly, equal pay for men and women is indeed a constitutional right in Switzerland, in contrast to many other jurisdictions. In addition, Swiss courts are not confined to the evaluation of evidence presented by the litigating parties, but can conduct their own investigations. Nevertheless, the distribution of the litigation risk is very unevenly spread. The probability of an equal pay case being brought against a Swiss company is below 1:12,000. By contrast, only $7 \%$ of female private sector workers who took their employer to court were keeping their posts after litigation (Imboden, 2008). This is not surprising considering that 'action still falls to be taken by those discriminated against, rather than

\footnotetext{
${ }^{7}$ Although political strikes are not protected by law, on 19 October 1990 the SGB-USS congress surprisingly passed a resolution calling for the organisation of a day-long national women's strike (Eidgenössische Kommission für Frauenfragen, 2001; Schöpf, 1992; Wicki, 1991).
} 
by those in positions of power' (Dickens, 2006, p. 304). Given the strong political will in favour of EPG, however, why have Swiss policymakers nevertheless chosen a liberal implementation regime, despite its apparent ineffectiveness?

In the mid-1980s, unions and women's organisations were very critical of the fact that the Swiss authorities had failed to implement the 1981 equality amendment to the Constitution. They jointly called for the constitutional EPG clause to be applied directly and argued in favour of a speedy introduction of equality legislation. In 1986 the federal government established an expert group with the remit of examining pay inequality and presenting appropriate policy solutions. As is customary in Swiss politics, the expert group was composed of interest group representatives, civil servants and academic experts. Whereas unions and women's organisations had already supported the intention of the Swiss federal government to enact a gender equality act in the pre-parliamentary phase of the policymaking process, employer organisations disputed both the need and likely effectiveness of legislative action. In addition, employers worried about legislation interfering with the autonomy of private enterprise (Kaufmann, 2009). After the national women's strike of June 1991 and the lobbying of traditional, middle-class women's organisations, however, Switzerland's mainstream centre-right parties also supported the GEA proposal in parliament, despite continued employer resistance. In addition, the pro-European mainstream parties of both the centre-right and the centre-left supported the GEA in order to act in accordance with EU law (Parlamentsdienste, 1995; Fuchs, 2013).

Employer opposition did not prevent the adoption of the GEA. Nevertheless, it effectively excluded the adoption of a corporatist implementation regime for the equal pay policy for men and women. The federal government gave 'very heavy weighting' to the objections of employer organisations (Kaufmann, 2009, p. 16). As a result, the demands for an authority with investigative powers, the right to inspect documents and the right to information in relation to individuals - which had received majority support during the consultation process-were rejected during the legislative process due to employer opposition. The federal government also decided not to grant special investigative powers to the Federal Office for Gender Equality as 'employers were particularly worried about the Swiss government interfering in their autonomy and in the workplace' (Bundesrat, 1993, p. 1274). Although academic economists stressed that an effective implementation of equal pay policies would increase economic efficiency and enhance labour market performance (Littmann-Wernli, 1991), these voices failed to influence the preferences of Swiss employers. Hence the GEA failed to assign any role either to social partners or to governmental agencies in the implementation of the act, despite their significant role in other areas of pay determination. As a result, a government-appointed expert group concluded, the effect of the act remains very limited (Stutz et al., 2005).

The interest politics dynamics that shape the formation of a public policy also influence its implementation. It is thus hardly surprising that employer resistance is also evident at the level of execution. The implementation of a particular policy is often determined less by its own characteristics than by the context of its conception; this latter defines the frame of reference for the implementation of the policy by the implementation actors. Therefore the implementation of the equal pay principle for men and women is left to voluntary, non-binding measures that aim to raise employers' awareness and to equally ineffective litigation processes. In 2008 the Swiss governmental department responsible for GEA implementation reiterated its preference for 
'voluntary approaches rather than state coercion' (Bundesamt für Justiz, 2008) and initiated a 'wage-equality dialogue' with the goal of persuading 100 companies to accept an econometric assessment of their employees' wages and pay scales within five years; however with very limited success.

Nevertheless, gender equality issues have played a greater role in the negotiation agenda of social partners, first and foremost because of union pressure. As late as 1993, every sixth CLA included wage categories - such as 'light work' and 'heavy work'that indirectly discriminated against women (Baumann et al., 1995). Meanwhile, progress has been made with regard to equal pay. Part-time employees are now covered by CLAs. Furthermore, commitments have been made to enshrine gender equality in different sectors and, in a few cases, new instruments, such as the gender equality commission in the metal manufacturing industry, have been introduced. Opposition from employers and the low level of union organisation in sectors with a high number of female employees mean, however, that collective bargaining results in terms of equal pay are still very inadequate. In addition, the organisational power of women within unions continues to be relatively weak (Ballmer-Cao, 2000; Monney et al., 2013), although the percentage of female union members has doubled since the 1991 women's strike. Within the SGB-USS, the percentage of women increased from a low of $12.7 \%$ in 1990 to $27.4 \%$ in 2010 (Schweizerischer Gewerkschaftsbund, 2011, p. 12).

The biggest obstruction on the way to equal pay for men and women, however, remains sustained employer resistance. Given the substantial costs of the wage increases that would be required to eliminate the gender pay gap, employer opposition against a more effective GEA is not surprising. It must also be noted, however, that the GEA is not the only act promoting equal pay. Swiss procurement legislation requires companies bidding for tenders to adhere to the principle of wage equality between women and men. As a result, the federal government has developed an analytical instrument based on econometric regression analysis in order to investigate wages paid in companies that respond to public tenders (Eidgenössisches Büro für die Gleichstellung von Frau und Mann, 2006; Chicha, 2006). But whereas policy debates about the GEA were framed in terms of equal rights for men and women, the policy debate in the case of the Swiss procurement legislation centred on the avoidance of a distortion of competition that is disadvantageous to fair employers. Intriguingly, the latter frame of reference proved also to be of utmost importance in the following, second case of our analysis.

\section{Equal pay for workers of different origins: a more effective neocorporatist solution}

Despite the Swiss electorate's narrow rejection of entry into the European Economic Area (EEA) in 1992, Switzerland subsequently opened its market to workers and service providers from the EU. The opening of the Swiss labour market represented a radical change in Swiss migration and labour market policy. Hitherto, Swiss labour market policy had been characterised by a discriminatory system of employment permits for migrant workers, which initially had also been supported by the trade unions (Schmitter, 1981; Steinauer, 2006).

After the prospect of both EEA and direct EU membership evaporated, EU and Swiss policymakers chose a bilateral approach instead and successfully negotiated a package of bilateral Switzerland-EU agreements, which led to Switzerland's integration 
into the Single Market. In order to facilitate the ratification of the AFM in a popular referendum, Swiss policymakers attached a legislative package of accompanying measures to the Switzerland-EU agreements to facilitate the enforcement of the principle of equal pay for workers of different origins. These measures were agreed in 1999 and came into effect in June 2004. As a result, both Swiss and foreign employees were to be protected from an undercutting of wages in Switzerland. Hence pay and employment conditions are no longer linked to an employee's origin; instead, Swiss migration and labour law focuses upon the protection of employment conditions of all employees, independent of origin. Abusive undercutting of Swiss wage and employment conditions are to be combated with the help of the following acts and measures.

Firstly, a new federal Posted Workers Act (Entsendegesetz, EntsG) stipulates that workers transferred to Switzerland for the purpose of providing a service are subject to the wage and employment conditions that apply in Switzerland. The EntsG also enables federal and cantonal authorities to impose binding minimum wage conditions as part of a normal employment contract in sectors not covered by CLAs.

Secondly, a reinforced federal act on the extension of CLA (Bundesgesetz über die Allgemeinverbindlicherklärung von Gesamtarbeitsverträgen) facilitates the legal extension of CLAs to all employers and employees operating in a particular economic sector.

Finally, the accompanying measures also include the setting up of tripartite commissions, with extensive law enforcement powers, composed of employer, union and state representatives at federal and cantonal levels. Interestingly, however, in this policy field, Swiss equal pay policy has not been framed in terms of the anti-discrimination language that guides the GEA and the AFM. On the contrary, the primary goal of the revised legislation is 'to prevent social dumping and wage dumping that is disadvantageous for employees in Switzerland' (Bundesrat, 1999, p. 6392).

The accompanying measures are a good example of the functioning of Swiss neocorporatism (Oesch, 2007). Given that 'unions have traditionally been the junior partner in Switzerland's corporatist arrangements' (Oesch, 2011, p. 84), however, the substantial curtailment of employers' management prerogatives by the measures requires an explanation: 'Less than a decade after prominent business representatives had declared collective agreements a model of the past, employer associations had to accept the reinforcement of collectively agreed minimum wages, the facilitation of extension clauses and the hiring of works inspectors' (Oesch, 2011, p. 92).

According to the liberal theory that has dominated Swiss economic policy for decades, employers should resist collective labour market regulations, especially with regard to wages. Accordingly, Swiss employer associations always clearly rejected requests for the introduction of a statutory minimum wage. Until very recently, important Swiss employer associations even resisted wage provisions in sectoral collective agreements. The so-called peace agreement between Swiss metalworkers' unions and the Employer Association of the Swiss Mechanical Engineering Industry dating back to 1937 (Fluder and Hotz-Hart, 1998), for example, did not contain any minimum wage provisions until 2013. It is therefore not surprising that the Swiss federation of employer associations reiterated in 2011 that 'the regulation of wages is the responsibility of company owners or shareholders. ... There is no acceptable reason for state interference' (Schweizerischer Arbeitgeberverband, 2011, p. 3). Even so, a majority of Switzerland's employer organisations de facto accepted the contrary when they endorsed the accompanying measures in 1999. 
Employers' support for the accompanying measures can be explained as follows. Firstly, Switzerland's employers were divided. Important export-oriented Swiss companies, especially in industry, were against these measures as they would decrease their international competitiveness. In turn, the more domestic-oriented companies, especially in the construction industry, fully supported the measures that aimed to prevent unfair competition from competitors who would not adhere to Swiss wage agreements and working conditions. Secondly, the measures' tripartite implementation structures that guaranteed employers direct access to the policy implementation regime also alleviated some fears of unreasonable state interventionism. It is, however, reasonable to suggest that the proponents of the accompanying measures within Switzerland's employer organisations would not have been able to overcome the internal employer opposition if Swiss unions had not been able to use the popular referenda about the bilateral Switzerland-EU agreements as an effective 'political lever' (Wyler, 2012).

Despite Switzerland's relatively low union density rate of only 16.2\% (OECD, 2013), Swiss unions have often been able to veto undesirable legislative proposals (Fischer, 2003). Although economic globalisation and Europeanisation processes repeatedly led to a decline of union power in most countries, the recurrent need to ensure popular majorities in favour of a continuous integration of Switzerland in transnational markets ironically provided Swiss unions an opportunity in which they were able to make use of considerable political mobilisation and exchange power (Afonso, 2010, 2012; Afonso et al., 2010; Wyler, 2012). After the rejection of EEA membership in the popular referendum in 1992-despite the SGB-USS leadership's unconditional support for EEA and even EU membership - Switzerland's union leaders could convincingly argue that further economic integration would only gain popular support if workers' fears about a race to the bottom in wages and labour standards were addressed. At the same time, a new, more radical generation of union leaders came to power. Moreover, Swiss unions adopted much more inclusive union attitudes towards migrant workers and this in turn led to important changes in union membership structure (Steinauer and Allmen, 2000; Arlettaz and Arlettaz, 2006). Until the 1992 EEA referendum, Swiss union policy primarily reflected the concerns of the predominately Swiss workers employed in the export industry. After 1992, however, union policy increasingly emphasised the concerns of Switzerland's domestic-oriented sectors, ironically also because unions proved to be much more successful in organising the migrant workers employed in construction and other domestic sectors.

Whereas export-oriented union leaders argued in the 1992 EEA referendum that the threat of wage dumping was 'not all that great' and even conducted a joint Yes campaign with employer organisations (Wyler, 2012, p. 137), employers and unions operating in domestic sectors endorsed the EEA agreement much more reluctantly. In 1989 the construction workers' union was already demanding measures against the undercutting of wages through the introduction of the 'local wage principle' for posted workers and asked the SGB-USS to envisage a 'popular initiative' against wage dumping. This idea re-emerged when the union confederation discussed its recommendation to voters in relation to the EEA referendum. At the time of the EEA vote, however, the idea of accompanying measures against wage dumping was far from reaching overall consensus, even within the labour movement. Before the EEA vote, not only employers but also a leading unionist from the export-oriented manufacturing sector attacked the 'cartel-like' agreements between social partners in the domestic market that would be detrimental to consumers and taxpayers (Ghelfi, cited in Wyler, 2011, pp. 150-1). After 
the negative outcome of the EEA referendum, however, the situation changed. The No vote caused uproar within the union movement for two reasons: not only had Swiss union leaders to concede that they had not obtained any concessions from employers and the government in exchange for their support for the EEA agreement, but also they learned that the unions' rank and file did not follow the union leadership's voting recommendations. Consequently, the Swiss unions changed their strategy in relation to the subsequent bilateral agreements between Switzerland and the EU that replaced the rejected EEA agreement. Instead of adopting a 'Yes But' approach as in the EEA case, the Swiss unions threatened to campaign for a No vote in subsequent European integration referenda if their demands for accompanying measures were not integral to subsequent referenda packages. This change in union strategy was very effective, since the Swiss social partners agreed in April 1999-before the Swiss government started its official consultation process - that accompanying measures against social dumping were needed to secure the adoption of new bilateral agreements between Switzerland and the EU. Despite neoliberal criticism about the increased union influence (Schmid, 1999), the agreement between Swiss employer associations and unions essentially preempted the later legislation by jointly calling for a 'Swiss posted workers act', the 'local wages for posted workers principle' and 'legislation against misuse' of the free movement of workers and services (Wyler, 2012).

Arguably, the 1999 agreement on accompanying measures represented a great success for the SGB-USS. Its implementation, however, also depended on the capacity of the SGB-USS to overcome its internal divisions between unionists from exportoriented and from domestic-oriented sectors of the economy. The Unia trade union merger between the metalworkers' union (SMUV) and the construction workers' union (GBI), which took place in 2005, is certain to have played a key role here. It led to a shift of the SGB-USS's centre of attention away from the export industry towards more domestic market-oriented sectors. Another change in the union movement with regard to membership must also be considered. The percentage of members from an immigrant background grew from $32 \%$ in 1986 to around $40 \%$ in 2007 . Since the middle of the 1980s, several unions have had a majority of members from an immigrant background (Allmen and Steinauer, 2000, p. 43). This is exceptional compared with the rest of Europe (Erne, 2008, pp. 90-4). Nevertheless, there are still fewer nonnationals than women present in Swiss unions' federal governance structures.

Since the accompanying measures came into force in 2004, the Swiss federal government and the cantons can enact minimum wages in cases of repeated abuse. A normal employment agreement with a binding minimum wage, however, can only be enacted under certain conditions, particularly if customary local wages are repeatedly undercut within a sector or a specific occupational field. In 2008, for example, the federal tripartite commission successfully requested the introduction of a federal minimum wage for domestic service to prevent the predominately female workers from Eastern Europe being paid wages well below customary Swiss levels when employed in Swiss households (Alleva and Moretto, 2011).

The tripartite commissions are made up of equal numbers of representatives of authorities, employers and unions. In sectors with legally binding collective agreements, however, this task is delegated to social partners' existing bipartite CLA committees. In 2010 the bi- and tripartite commissions controlled the wages and labour standards of 142,535 workers employed in 36,451 companies. Of those, 99,789 workers were employed by Swiss companies and 42,746 where either self-employed or 
employees of a foreign firm (Staatssekretariat für Wirtschaft, 2011, p. 18). In addition, the parliamentary commission of the lower house in charge of policy implementation found that every second person posted to Switzerland by a foreign company is inspected and that controls are more frequent in sectors with bipartite social partnership institutions. In the construction industry, for example, the payroll accounts of $50 \%$ of all workers have been inspected to ensure compliance with the collectively agreed minimum wage. A high number of infringements have been detected in this area. The percentage of infringements was around $60 \%$, resulting in significant fines and/or back payments (Geschäftsprüfungskommission, 2011, p. 21). According to Article 2.2 EntsG, the commissions set up by collective agreements that have been declared universally applicable can enforce the payment of substantive contractual penalties without delay if an employer refuses to 'voluntarily' pay outstanding wages within a given time period.

Because of the high number of inspections, a range of avoidance strategies are being used by opportunistic employers. There has also been an increase in bogus self-employment. In addition, subcontracting and temporary employment is booming. This is especially prevalent in the construction industry and related trades. The responsible parliamentary commission concluded that 'the system of accompanying measures is based upon a central element of the Swiss economy: the relations between social partners'. This, however, also means that 'in areas where social partners have traditionally been less active, the accompanying measures have hardly been attained at all' (Geschäftsprüfungskommission, 2011, p. 18). The implementation of accompanying measures also varies greatly across cantons, reflecting Switzerland's federal governance structure, differences in regional labour markets' international exposure and different regional balances of power between social and political forces.

The weaknesses of the accompanying measures mentioned above and employers' ingenuity in finding various ways around them, however, also led to the adoption of two additional packages of accompanying measures. The second package was put to a referendum in 2005 in conjunction with the vote on the extension of the AFM for the then $10 \mathrm{EU}$ accession countries. A third package proved instrumental in getting a clear Yes vote in the 2009 referendum about the extension of the AFM to Romania and Bulgaria. ${ }^{8}$

A fourth package of accompanying measures was discussed in 2013, in view of the popular vote on the anti-immigration initiative of the far-right Swiss People's Party (SVP-UDC) and a planned referendum about the extension of the AFM to Croatia. However the negotiations about the fourth package largely failed, as the social partners and the mainstream pro-European centre-right and centre-left parties failed to agree a joint position on the further strengthening of the accompanying measures, with the exception of a new provision that makes main contractors liable for their subcontractors' unpaid wages. After Switzerland's pro-European forces narrowly lost the popular vote on the SVP-UDC initiative 'against mass immigration' on the 9 February 2014 by a very slim 50.3 to $49.7 \%$ majority, union leaders attributed this defeat to the employers and authorities that 'baulked at any further tightening of the flanking measures even though this was urgently needed' (Rechsteiner et al., 2014).

\footnotetext{
${ }^{8}$ The continuous reinforcement of these accompanying measures proved crucially important in securing Yes votes in the two subsequent Swiss referenda about the extension of the AFM to 10 new EU member states (25 September 2005:Yes vote, 56\%) and to Bulgaria and Romania (8 February 2009: Yes vote, 60\%).
} 


\section{Discussion}

It is has been shown that the unequal implementation of Switzerland's equal pay policies cannot be the result of different levels of political support, as the EPG and EPN regimes had both been endorsed by the same government and similar majorities in parliament. Yet clear differences between the two cases become apparent when the corresponding dynamics of interest politics are compared.

Most importantly, Switzerland's employer organisations consistently resisted political interventions aimed at curbing the gender pay gap. In contrast, these associations supported the accompanying measures that ensure equal pay for workers of different origins. Although the measures openly contradicted the neoliberal policy agenda set by Switzerland's leading capitalists in 1995 (De Pury et al., 1995), Swiss employer organisations supported the legal extension of collective bargaining agreements, the declaration of statutory minimum wages in some sectors that had no collective bargaining agreements and the bi- and tripartite commissions with extensive powers to enforce the payment of customary local wages for workers of different origins. The opposite stances adopted by the employer organisations led to very different regulatory implementation strategies in the two parallel cases. Whereas the GEA is based on a liberal litigation-based model of policy implementation that obliges those discriminated against to take action, the accompanying measures are implemented by neocorporatist policy networks. It is therefore hardly surprising that the principle of equal pay is implemented very unequally across the two cases.

Women and women's organisations arguably play a more important role in Swiss politics than migrants and migrants' organisations. Whereas women's votes have secured a continuous extension of women's rights since 1971 (Mottier, 1995), most propositions aimed at extending the rights of immigrants have been frequently rejected in Swiss referenda. In addition, women's organisations were effectively involved in the pre-parliamentarian policymaking processes in the GEA case, whereas migrants' interests were only indirectly represented by unions. Surprisingly, however, women's groups' higher levels of access and mobilisation in the political process did not lead to the adoption of a more efficient equal pay policy. Hence EPG and EPN policy regimes and outcomes do not vary because of the relevant groups' different levels of political mobilisation, as recurrently assumed.

Variation is better explained by different interest politics dynamics and the particular frames of reference that guide the policymaking process in a particular field. If we compare the policy framework in our two parallel cases, notable differences can be discerned. Whereas equal pay policies for men and women are framed in the language of anti-discrimination policy, the principle of equal pay for workers of different origins enshrined in the accompanying measures is aimed at guaranteeing a level playing field for all companies in a given sector. The Swiss gender pay gap policy debate has been framed as a debate about the reallocation of money from capital to female workers. Consequently, it is not surprising that employer organisations resisted effective EPG interventions. In contrast, the Swiss policy debate about equal pay for workers of different origins was not portrayed as a conflict that sets different class interests against one another. Instead, the debate was framed in non-distributive terms as a debate about employment practices that undermine fair competition. The employer organisations endorsed this policy to prevent unfair competition from free-riders who refuse to adhere to collectively agreed wage settlements and to increase the popular support for 
Switzerland's participation in the Single European Market. On the other hand, both Swiss and migrant workers supported the measures because they are an effective tool in the fight against social dumping and for equal pay and working conditions.

However, the adoption of the accompanying measures also required a certain balance of class forces, as in neocorporatist arrangements generally, as well as a particular balance of power within the organisations of capital and labour. Switzerland's major union confederation, the SGB-USS, would have hardly been able to threaten a No vote recommendation in the recurrent referenda on bilateral EU-Switzerland agreements in the event of failure to provide adequate accompanying measures, if the centre of gravity within the SGB-USS had not shifted from export-oriented to domesticoriented sectors during the 1990s. Swiss unions' exceptional successes in organising migrant workers in the 1990s also made a substantial difference. The increased effort to secure equal pay for workers of different origins reflects the increased presence of migrant workers in Swiss unions as much as the increased influence of the unions that organise construction and private service workers' unions within the SGB-USS.

The narrow victory of the SVP-UDC initiative on 9 February 2014, which can in part be attributed to the lack of renewal of the class compromise in favour of accompanying measures that had hitherto been sustaining the AFM, shows that corporatist compromises are inherently fragile. After the employer organisations and the Liberals (FDP-PLR) prevented a further extension of the accompanying measures, neither the Liberals and Christian-Democrats nor the Social-Democrats (SP-PS) and Greens campaigned passionately against the SVP-UDC proposal. After the vote, the FDP-PLR president justified his party's stance by stating that there is a point at which the regulatory costs of further 'illiberal' accompanying measures simply exceed the benefits from the bilateral agreements with the EU (Müller, 2014). It remains to be seen whether organised capital and organised labour will manage to find common ground on the free movement of people and the renewal of the accompanying measures before Switzerland's voters will be asked again to determine their country's future relationship with the EU in 2016 or 2017 . Given the clear determination of the employers' associations and unions to save the bilateral agreements with the EU, it seems, however, rather unlikely that far-right politicians and employers will succeed in dismantling the existing accompanying measures that are meant to enforce the EPN principle. In this context it is also noteworthy that the rejection of strict immigration limits in the recent popular vote on the so-called 'Ecopop initiative' by $74 \%$ of the Swiss voters on 30 November 2014 has been interpreted by the major parties as a 'Yes to the bilateral treaties with the EU' (Geiser, 2014).

\section{Conclusion}

Our analysis suggests that the liberal frames of references of gender equality policy which are predicated on individual anti-discrimination law - do not provide the most effective policy framework for the closure of the gender pay gap. The more equal pay policies were framed in terms of providing a level playing field for competing firms, the more they were acceptable to organised capital. And the more employer organisations were supportive of equal pay policy principles, the more effectively they can be implemented through collective, corporatist policy regimes. For this reason, our study provides a compelling argument for reframing gender equal pay policies to make them more acceptable for employer organisations, as in the case of EPN. Incidentally, the 
equal, level playing field argument had already proved to be critical in the discussions that led to the introduction of the EPG principle into the EEC Treaty in 1957 in the first place. If the French employers' had not feared the unfair competition of underpaid Italian female workers, the principle would not have been included in the Treaty (Hoskyns, 1996; Allais, 1960).

The history of the Swiss EPN regime, however, has also been a history of constantly 'moving goal posts' as in the EPG case (Rubery and Grimshaw, 2013). As long as we are living in a capitalist society, opportunistic employers will always try to find ways around labour and equality law. It must therefore be reiterated that the framing of equal pay policies as a 'beneficial constraint' (Streeck, 1997) is acceptable for business interests only if a particular set of power constellations sustain them (Wright, 2004). It would therefore be wrong to conclude that the findings of this study would justify a detached state, as simple 'business case' advocates for equal pay may be arguing. However beneficial equal pay policies may be for business as a whole, they must constrain every single company to be effective.

Finally, the comparison of equal pay policies by gender and by nationality not only turned out to be a good choice for the methodological reason outlined in Section 2 . The larger thematic scope of our equal pay study also helps to explain an unexpected policy shift in Switzerland's EPG regime. On 22 October 2014, the Swiss government proposed a substantive revision of the Gender Equality Act. If the amendment is enacted, companies with more than 50 employees would become subject to compulsory 'equal pay for work of equal value' audits of their pay structure, which must be conducted either jointly by trade unions and employer associations or by qualified external auditors (Bundesrat, 2014). The proposed amendment follows an expert group report, which first assessed different equal pay policy regimes (including the Swiss EPN regime) and then suggested the introduction of compulsory audits of companies' payroll accounts to close the gender pay gap (Müller et al., 2013). Once it becomes socially acceptable for external inspectors to get access to firms' payroll accounts to fight social dumping in relation to non-national workers, the more likely it is that the state will require external equal pay audits as well in order to tackle the gender pay gap.

\section{Bibliography}

Afonso, A. 2010. Policy concertation, Europeanization and new political cleavages: the case of Switzerland, European fournal of Industrial Relations, vol. 16, no. 1, 57-72

Afonso, A. 2012. Employer strategies, cross-class coalitions and the free movement of labour in the enlarged European Union, Socio-Economic Review, vol. 10, no. 4, 705-30

Afonso, A., Fontana, M. C. and Papadopoulos, Y. 2010. Does Europeanisation weaken the left? Policy \& Politics, vol. 38, no. 4, 565-82

Allais, M. 1960. L'Europe Unie, Paris, Calmann-Levy

Alleva, V. and Moretto, M. 2011. Domestic workers in Switzerland protected by the country's first sectoral employment contract, Global Labour Column, no. 47, http://www.global-labouruniversity.org/fileadmin/GLU_Column/papers/no_47_Alleva__Moretto.pdf [date last accessed: 29 January 2015]

Allmen, M. von and Steinauer, J. 2000. L'Apport de l'Immigration au Syndicalisme Suisse depuis 1945, Programme national de recherche 39 'Migrations et relations interculturelles', vol. 1, Genève, UOG

Arlettaz, S. and Arlettaz, G. 2006. Der Schweizer Gewerkschaftsbund und die Ausländer, pp. 118-21 in Boillat, V., Degen, B., Joris, E., Keller, S., Tanner, A. and Zimmermann, R. (eds), Vom Wert der Arbeit, Zürich, Rotpunkt 
Ballmer-Cao, T. H. 2000. Sozialer Wandel und Geschlecht. Zur Gleichstellungsfrage in der Schweiz, Bern, Haupt

Baumann, B., Bauer, T., Nyffeler, B. and Spycher, S. 1995. Gesamtarbeitsverträge (k)eine Männersache, Chur, Rüegger

Blau, F. D. and Kahn, D. 2003. Understanding international differences in the gender pay gap, Fournal of Labor Economics, vol. 21, no. 1, 106-44

Bundesamt für Justiz. 2008. Bericht über verschiedene Modelle von Behörden mit Untersuchungsund Durchsetzungskompetenzen im Bereich der Gleichstellung von Frauen und Männern im Erwerbsleben, https://www.bj.admin.ch/dam/data/bj/staat/gleichstellung/ber-gleichstellung-d. pdf [date last accessed: 29 January 2015]

Bundesrat. 1993. Botschaft zum Bundesgesetz über die Gleichstellung von Frau und Mann vom 24 Februar, http://www.amtsdruckschriften.bar.admin.ch/viewOrigDoc.do?id=10052580 [date last accessed: 29 January 2015]

Bundesrat. 1999. Botschaft zur Genehmigung der sektoriellen Abkommen zwischen der Schweiz und der EG vom 23 funi, http://www.admin.ch/opc/de/federal-gazette/1999/6128.pdf [date last accessed: 29 January 2015]

Bundesrat. 2014. Lohngleicheit: Bundesrat will zusätzliche staatliche Massnahmen ergreifen, Press Release, 22 October, http://www.ejpd.admin.ch/ejpd/de/home/aktuell/news/2014/2014-10221.html [date last accessed: 29 January 2015]

Caramani, D. 2009. Introduction to the Comparative Method with Boolean Algebra, London, Sage

Chaponnière-Grandjean, M. 1983. Geschichte einer Initiative, Zürich, Verlagsgruppe Gleiche Rechte für Mann und Frau

Chicha, M. T. 2006. 'A Comparative Analysis of Promoting Pay Equity: Models and Impacts', ILO Working Paper, no. 49, http://www.ilo.org/wcmsp5/groups/public/---ed_norm/---declaration/documents/publication/wcms_decl_wp_27_en.pdf [date last accessed: 29 January 2015]

Conley, H. 2012. Using equality to challenge austerity: new actors, old problems, Work, Employment \& Society, vol. 26, no. 2, 349-59

Crouch, C. 2005. Capitalist Diversity and Change, Oxford, Oxford University Press

Crouch, C. 2009. Typologies of capitalism, pp. 75-94 in Hancke, B. (ed.), Debating Varieties of Capitalism, Oxford, Oxford University Press

De Pury, D., Hauser, H. and Schmid, B. 1995. Mut zum Aufbruch. Eine Wirtschaftspolitische Agenda für die Schweiz, Zürich, Orell Füssli

Deakin, S., Fraser-Butlin, F., McLaughlin, C. and Polanska, A. 2013. Equal Pay, Litigation Strategies and the Limits of the Law, paper presented at the CfE Symposium 'Equal Pay: Fair Pay?' Cambridge, 7-8 June

Dickens, L. 1999. Beyond the business case: a three-pronged approach to equality action, Human Resource Management Fournal, vol. 9, no. 1, 9-19

Dickens, L. 2006. Re-regulation for gender equality: from 'either/or' to 'both', Industrial Relations Fournal, vol. 37, no. 4, 299-309

Eidgenössisches Büro für die Gleichstellung von Frau und Mann. 2006. Methodisches Vorgehen zur Überprüfung der Lohngleichheit zwischen Frau und Mann im Beschaffungswesen des Bundes, http://www.ebg.admin.ch/dienstleistungen/00017/index.html?lang=de [date last accessed: 10 January 2012]

Eidgenössische Kommission für Frauenfragen (eds) 2001. Frauen. Macht. Geschichte, http:// www.ekf.admin.ch/dokumentation/00444 [date last accessed: 29 January 2015]

Erne, R. 2008. European Unions: Labor's Quest for a Transnational Democracy, Ithaca, Cornell University Press

Erne, R. 2013. National unionism and union democracy in crisis, Labor History, vol. 54, no. 4, $471-6$

Erne, R. 2014. Interest groups, pp. 237-51 in Caramani, D. (ed.), Comparative Politics, 3rd edn, Oxford, Oxford University Press

Eurostat. 2013. Gender Pay Gap in Unadjusted Form by Economic Control, ec.europa.eu/eurostat/ statistics-explained/images/2/20/Corrected_unadjusted_GPG_March_update.xls [date last accessed: 29 January 2015]

Fagan, C., Grimshaw, D. and Rubery, J. 2006. The subordination of the gender equality objective: the National Reform Programmes and 'making work pay oplicies [sic], Industrial Relations fournal, vol. 37, no. 6, 571-92 
Fischer, A. 2003. Vetospieler und die Durchsetzbarkeit von Side-Payments, Swiss Political Science Review, vol. 9, no. 2, 27-58

Fiss, P.C. 2007. A set-theoretic approach to organizational configurations, Academy of Management Review, vol. 32, no. 4, 1180-98

Fluder, R. and Hotz-Hart, B. 1998. Switzerland: still as smooth as clock work? pp. 262-82 in Ferner, A. and Hyman, R. (eds), Changing Industrial Relations in Europe, Oxford, Blackwell

Fuchs, G. 2008. Suisse: droits des femmes - un chemin libéral vers l'égalité? Chronique internationale de l'IRES, vol. 17, no. 113, 32-42

Fuchs, G. 2010. Strategische Prozessführung, Tarifverhandlungen und Antidiskriminierungsbehörden — verschiedene Wege zur Lohngleichheit? Femina Politica, vol. 19 , no. 2, 102-11

Fuchs, G. 2013. Strategic litigation for gender equality in the workplace and legal opportunity structures in four European countries, Canadian fournal of Law and Society, vol. 28, no. 2, 189-208

Galtung, J. 1990. Theory formation is social research: a plea for pluralism, pp. 96-112 in Øyen, E. (ed.), Comparative Methodology, London, Sage

Geiser, U. 2014. Strict Immigration Curbs Overwhelmingly Rejected, http://www.swissinfo.ch/eng/ ecopop-opener/41132200 [date last accessed: 29 January 2015]

Geschäftsprüfungskommission. 2011. Evaluation der Aufsicht über die flankierenden Massnahmen zur Personenfreizügigkeit und deren Wirkungen, http://www.parlament.ch/d/dokumentation/berichte/berichte-aufsichtskommissionen/geschaeftspruefungskommission-GPK/berichte-2011/ Documents/bericht-gpk-n-flank-massnahmen-2011-10-21-d.pdf [date last accessed: 29 January 2015]

Grote, J. R. and Schmitter, P. C. 1999. The renaissance of national corporatism, Transfer: European Review of Labour and Research, vol. 5, nos 1-2, 34-63

Guillaume, C. 2013. Equal Pay and Trade Unions: Understanding the Variations of Unions' Legal Mobilisation in the UK (1960-2010), paper presented at the CfE Symposium 'Equal Pay: Fair Pay?' Cambridge, 7-8 June

Hoskyns, C. 1996. Integrating Gender:Women, Law and Politics in the European Union, London, Verso

Imboden, N. 2008. Vollzugsnotstand bei der Lohngleichheit, pp. 117-33 in Arioli, K., Cottier, M., Farahmand, P. and Küng, Z. (eds), Wandel der Geschlechterverhältnisse durch Recht? Zürich, DIKE-Verlag

Joris, E. and Witzig, H. (eds) 2001. Frauen-Geschichte(n), 4th edn, Zürich, Limmat

Kantonsgericht Basel-Landschaft. 2012. Entscheid vom 17 Dezember 2012, Missbräuchliche Kündigung: Lohnsenkung für Grenzgänger wegen dem schwachen Euro (Rachekündigung und Verletzung des FZA), no. 40012152

Kaufmann, C. 2009. Hintergrund und Entstehung, pp. 1-29 in Kaufmann, C. and SteigerSackmann, S. (eds), Kommentar zum Gleichstellungsgesetz, Frankfurt am Main, Helbling Lichtenhahn

Kriesi, H. P. and Trechsel, A. H. 2008. The Politics of Switzerland, Cambridge, UK, Cambridge University Press

Littmann-Wernli, S. 1991. Auswirkungen eines Diskriminierungsverbotes und eines verstärkten Kündigungsschutzes, LeGes, vol. 2, no. 2, 31-81, www.bk.admin.ch/themen/ lang/00938/02124/06128/index.html? [date last accessed: 29 January 2015]

Luhmann, N. 1989. Law as a social system, Northwestern University Law Review, vol. 83, nos $1-2,139-50$

McLaughlin, C. 2014. Equal pay, litigation and reflexive regulation: the case of the UK local authority sector, Industrial Law fournal, vol. 43, no. 1, 1-28

Monney, V. Fillieule, O. and Avanza, M. 2013. Les souffrances de la femme-quota, Genre travail et société, no. 30, 33-51

Mottier, V. 1995. Citizenship and gender division in Swiss direct democracy, West European Politics, vol. 18, no. 1, 161-72

Müller, F., Itin, A., Schwenkel, C., Wyttenbach, J. and Ritz, A. 2013. Staatliche Kontroll- und Durchsetzungsinstrumente zur Verwirklichung der Lohngleichheit, http://www.ejpd.admin.ch/ content/dam/data/bj/staat/gleichstellung/ber-interface-d.pdf [date last accessed: 29 January 2015] 
Muller, P. 2005. Esquisse d'une théorie du changement dans l'action publique, Revue française de science politique, vol. 55, no. 1, 155-87

Müller, P. 2014. Intervention during the party leaders' debate, Swiss Television SFR 1, 9 February

Naumann, I. K. 2005. Child care and feminism in West Germany and Sweden in the 1960s and 1970s, Fournal of European Social Policy, vol. 15, no. 1, 47-63

OECD. 2013. Trade Union Density, http://stats.oecd.org/Index.aspx?QueryId=20167 [date last accessed: 29 January 2015]

Oesch, D. 2007. Weniger Koordination, mehr Markt? Swiss Political Science Review, vol. 13, no. 3, 337-68

Oesch, D. 2011. Swiss trade unions and industrial relations after 1990, pp. 82-102 in Trampusch, C. and Mach, A. (eds), Switzerland in Europe, London, Routledge

Parlamentsdienste. 1995. Rückblick auf die 44. Legislaturperiode, 93.024, http://www.parlament. $\mathrm{ch} /$ poly/rueckblick/d/retro01/93024.HTM [date last accessed: 29 January 2015]

Ragin, C. 1989. The Comparative Method, Berkley, University of California Press

Rechsteiner, P., Rieger, A. and Ambrosetti, R. 2014. The outcome of the people's initiative in Switzerland, Social Europe fournal, 20 February, http://www.social-europe.eu/2014/02/peoples-initiative/ [date last accessed: 29 January 2015]

Rubery, J. 2011. Towards a gendering of the labour market regulation debate, Cambridge fournal of Economics, vol. 35, no. 6, 1103-26

Rubery, J. and Grimshaw, D. 2013. The Forty Year Pursuit of Equal Pay: A Case of Constantly Moving Goal Posts, paper presented at the CfE Symposium 'Equal Pay: Fair Pay?' Cambridge, 7-8 June

Rueda, D. and Pontusson, J. 2000. Wage inequality and varieties of capitalism, World Politics, vol. 52, no. 3, 350-83

Sassen, S. 1988. The Mobility of Capital and Labour: A Study in International Investment and Labour Flow, Cambridge, UK, Cambridge University Press

Schmid, H. 1999. Systemveränderung durch die Hintertür? Neue Zürcher Zeitung, 21.8

Schmitter, B. E. 1981. Trade unions and immigration politics in West Germany and Switzerland, Politics E Society, vol. 10, no. 3, 317-34

Schmitter, P. C. and Grote, J. R. 1997. 'The Corporatist Sisyphus: Past, Present and Future', EUI Working Paper no. SPS 1997/04, http://hdl.handle.net/1814/284 [date last accessed: 29 January 2015]

Schneider, C. Q. and Wagemann, C. 2012. Set-theoretic Methods for the Social Sciences: A Guide to Qualitative Comparative Analysis, Cambridge, UK, Cambridge University Press

Schöpf, E. 1992. Frauenstreik, Bern, Zytglogge Verlag

Schweizerischer Arbeitgeberverband. 2011. Positionspapier Mindestlohn, http://www.arbeitgeber. ch/files/Wahlplattform/Positionspapier_Mindestlohn.pdf [date last accessed: 29 January 2015]

Schweizerischer Gewerkschaftsbund. 2011. 'Zur Mitgliederentwicklung der Gewerkschaften im Jahr 2010', Dossier no. 81, Bern, SGB

Schweizerisches Bundesgericht. 2013. 'Urteil vom 18 September 2013', Case no. 4A_202/2013

Smith, M. 2012. Social regulation of the gender pay gap in the EU, European fournal of Industrial Relations, vol. 18 , no. $4,365-80$

Staatssekretariat für Wirtschaft. 2011. FlaM-Bericht vom 03 Mai 2011, Bern, Seco

Stan, S. and Erne, R. 2014. Explaining Romanian labor migration: from development gaps to development trajectories, Labor History, vol. 55, no. 1, 21-46

Steinauer, J. 2006. Überfremdung und die Gewerkschaften-das Schwarzenbach-Trauma, pp. 260-61 in Boillat, V., Degen, B., Joris, E., Keller, S., Tanner, A. and Zimmermann, R. (eds), Vom Wert der Arbeit, Zürich, Rotpunkt

Steinauer, J. and Allmen, M. von. 2000. Changer la Baraque. Les Immigrés dans les Syndicats Suisses 1945-2000, Lausanne, Editions d'en bas

Streeck, W. 1997. Beneficial constraints: on the economic limits of rational voluntarism, pp. 197219 in Hollingsworth, J. R. and Boyer, R. (eds), Contemporary Capitalism: The Embeddedness of Institutions, Cambridge, UK, Cambridge University Press

Stutz, H., Schär Moser, M. and Freivogel, E. 2005. Evaluation der Wirksamkeit des Gleichstellungsgesetzes, https://www.bj.admin.ch/dam/data/bj/staat/gleichstellung/synthesebergleichstellung-d.pdf [date last accessed: 29 January 2015] 
United Nations Economic Commission for Europe. 2013. Labour Force by Age, Sex, Measurement, Country and Year: Statistical Database, http://w3.unece.org/pxweb/database/STAT/30-GE/03WorkAndeconomy/?lang=1 [date last accessed: 29 January 2015]

Wicki, M. (ed.) 1991. Wenn Frauen wollen, kommt alles ins Rollen. Der Frauenstreik vom 14 Juni 1991, Zürich, Limmat Verlag

Wright, E. O. 2004. Beneficial constraints: beneficial for whom? Socio-Economic Review, vol. 2, 407-14

Wyler, R. 2011. Schweizer Gewerkschaften und Europa (1960-2005), PhD thesis, Universität Zürich

Wyler, R. 2012. Schweizer Gewerkschaften und Europa, 1960-2005, Münster, Westfälisches Dampfboot 